\title{
Character Building in Early Childhood Through Traditional Games
}

\author{
Eny Nur Aisyah \\ Early Childhood Education Program, State University of Malang, Indonesia \\ eny_aisyah@yahoo.com
}

\begin{abstract}
Traditional games start being forgotten and unknown among the children. The changes in children's playing activities are indentical to modern games. The level of children's addiction to the modern games are very high, so that it affects the children's habit and behavior. Modern games are very different with traditional games. Traditional games are able to build children's character. Reviving the traditional games as today's children's games can be an alternative to create a generation of noble character.
\end{abstract}

Keywords: traditional children's games, character building, early childhood

\section{INTRODUCTION}

Technological advances are increasingly rapidly it can affect children's play activities. Children more often play digital games such as video games, playstation, and online games. Games in the digital age use equipment that has advanced technology and cutting edge. Differences in technological sophistication can be seen when compared to traditional games. Some types of traditional children's games do not require equipment, but some other games require simple and easy-to-reach equipment. Traditional game tools are around where children play, such as rocks, twigs, or dried leaves.

The modern impression of digital games is not only attached to the equipment used while playing, but the conditions around the game. Digital games are generally performed in a comfortable room and equipped with air conditioning, such as a playground in a mall or cafe. The traditional game is far from the impression of a comfortable and closed environment.

Traditional games are generally done in the field or in the yard with a hot atmosphere. Children do physical activities that cause them to sweat like running, jumping, or throwing. Another difference is that digital games are available in malls or large stores that are generally located in downtown and areas near the city. Traditional games are often played by children on the edge of town or village. Ancient impression arises on traditional games that are considered out of date. The bad view of traditional games causes kids to prefer digital games. The child's choice also gets support from parents who provide various digital game facilities. Parents do not reintroduce traditional games to children.

Digital games have a negative impact on children. Print or electronic media is busy preaching the negative impact of digital games on children. Children who play online games without any special supervision from parents tend to get addicted. The impact is most of the time the child is used to play online games. Addictions to online games cause children to have difficulty in emotional development, concentration, and mind power (Shin, 2014). Bad addiction will not happen in traditional games. The Indonesian nation has a children's game that is rich in educational value and can stimulate child development.

The results show that traditional children's games can develop cooperation, help children adjust, interact positively, control themselves, develop empathy for friends, obey rules, and respect others. Traditional games can have a good impact in developing children's emotional and social skills. Preservation of Indonesian games is important to do by introducing and playing traditional games with children, along with socializing to parents about the negative impact of digital games. Parents are parties who have roles and responsibilities associated with online game addiction in children. The role of educators will not work optimally if parents do not supervise and pay attention to the growth and development of children.

\section{BUILDING CHILDREN CHARACTER THROUGH TRADITIONAL GAMES}

The period in a child's life is an identical time of play. The game is a play situation that is associated with certain rules or goals and produces activities in the form of intended actions. Activities that are bound by rules to achieve certain goals are present in the game. Mutiah (2010) also points out that the game and play are closely related to the development of the child's character. Human characters can be formed from an early age. The character is very different from the personality which is the permanent nature of man (Munir, 2010).

Play allows children to interact with the social environment, recognize and appreciate others because humans can not avoid differences in everyday life. Competence of social attitude is the capital of children to overcome differences in the environment (Kementerian Pendidikan dan Kebudayaan, 2014). The ability to work with understanding, empathy, and twoway communication skills is part of the much needed social skills in interaction.

Early childhood is required to have social skills to be able to co-exist with others and the environment. Children can learn to appreciate individual differences so that no bad situations occur. Play can teach children to reduce their ego, compete honestly, sportsmanship, care about the rights of themselves and others, and learn to communicate. Children when playing can feel a variety of emotions that is, happy, happy, tense, satisfied, or disappointed. Children can appreciate the feelings or emotions that are felt when playing. Social skills are not formed suddenly, but through imitation and habituation of the immediate environment of the child. 
Habitation begins with early childhood educators. Educators should be equipped with social skills knowledge for learners because the understanding of Kindergarten educators is minimal and some of the less programmed learning plans are clear (Nugraha \& Rachmawati, 2014). Unstructured activities and learning will result in an increase in the character of the child less than the maximum.

Proper play and play will have a positive impact on the child. Online games have a negative impact so online games are not the right game for kids. The rate of child addiction to online games in Indonesia is at a very high level. The impact is very apprehensive because it affects the learning achievement, child behavior, the tendency of children involved in criminal acts such as theft and rape, and cause children to experience multiple personalities. Digital games such as video games and online games are mostly played statically. Children play in a state of passivity. They sat and were silent, while only the fingers moved. The child becomes indifferent to the environment that will affect the child's social interaction. As a result of digital games is a child develops into a person who is shy, aloof, and individualistic. They will act aggressively and hurt friends.

Digital games also create a tense atmosphere and strong aggression. Children are formed unconsciously through digital games to tend to always want to win and will be very disappointed or can not accept defeat. The impact of digital games also affects the activity of the brain, the digital game causes decreased front brain activity that plays an important role in the control of emotions and activities, so the player or player quickly experienced emotional changes (irritability, often having problems in social interaction, and decreased concentration) causing a decrease in beta-wave activity that causes long-term effects. Negative effects persist even if the player or player is not playing the game. The signs that occur are increased adrenal hormone secretion, so that heart rate, blood pressure, and oxygen demand increase. The phenomenon of online games that occur in children in Indonesia should be dealt with by various actions and involving stakeholders.

The traditional game that is the culture of the Indonesian nation has been proven to foster positive character in children. Traditional games are often called folk games. Traditional games are a game that grew and developed in the past, especially among rural communities. The traditional game grows and evolves according to the needs of the local community. Traditional games are influenced by the natural surroundings and are always interesting and entertaining in accordance with the conditions of society. Traditional games are also recreative because they require the creation of children. Characteristic of the game is to reconstruct a variety of social activities in the community, such as playing the market that mimicked the activity of buying and selling, which mimicked Jaranan travel by horse, game-Menthogmenthog which symbolizes laziness, and others. Traditional games have a strong influence from the local culture. The traditional game changes, changes, additions, or reduces according to local conditions. The names of traditional games differ across regions, but have similarities or similarities in how to play.

There are several benefits of traditional games that can be used as a comparison with digital games, namely: (1) traditional games tend to use or utilize tools and facilities in the surrounding environment without having to buy, so that children at play require imagination and high creativity. Game tools made or used from plants, soil, tiles, stones, or sand. For example, car games made from bali orange peel, Egrang made from bamboo, Ecrak games using stones, used tin cans and nylon threads, and others; (2) traditional children's games involve relatively many players. The traditional game prioritizes shared pleasure factors and aims more in the deepening of interpersonal interpersonal skills (interpersonal potential), such as Petak Umpet, Congklak, and Gobak sodor; and (3) traditional games have noble values as well as certain moral messages, such as shared values, honesty, responsibility, broad-mindedness, achievement, and obedience to the rules. All will be obtained if the player really enjoys, enjoys, and understands the meaning of the game.

Traditional games can stimulate various aspects of child development that include the following: (1) motor aspects by training endurance, flexibility, coordination and balance of the body, motor sensory, motor, and fine motor. Activities in play include physical activities such as sports that develop skills in child growth; (2) cognitive aspects by developing imagination, creativity, problem solving, strategy, anticipatory ability, and contextual understanding so that abilities can be practiced in real life; (3) aspects of emotion by sharpening empathy and self-control. Traditional games help the child to communicate feelings effectively in a natural way, reduce anxiety, improve self-control, and concentration training; (4) aspects of language in the form of understanding of value concepts; (5) social aspect by conditioned the child in order to build relationships, cooperate, train social maturity with peers, and lay the foundation for improving social skills through role play; (6) the spiritual aspect of the traditional game can bring the child to be aware of the relationship with things that are Supreme or Divinity; (7) ecological aspect, which is to facilitate the child to understand the wise use of the natural elements around him; (8) the value aspect by facilitating the child to be able to live the moral values passed down from previous generations to the present generation; and (9) traditional games can detect early to identify problems that may occur in a child's life.

\section{TRADITIONAL GAMES FOR CHILDREN}

Indonesia has a lot of traditional games that are very much and different in every region, including Java. Javanese traditional games for early childhood are grouped into two, ie games involving gestures or physical (Sobyung, Amar-ambah Lemah, Obar-abir, Jenthungan or Dhelikan, Bedhekan or Tutup Tutup, Dhakon, Sundamanda or Engklek, Tumbaran, and 
Simbar Suru) as well as games involving motion and song (Cublak Suweng, Jamuran, Gundhul-gundhul Pacul, Jaranan, Uler Keket, Kidang Talun, Kursi Jebol, Lagu Kacang Goreng, Sluku-sluku Bathok, Siji Loro Telu, Menthog-menthog, Buta-buta Galak, Man Dhoblang, Tuku Kluwih, Pitik Walik Jambul, Kupu Kuwi, Iwak Emas, Jo Pra Kanca, Cah Dolan, I Duwe Pitik, Bang Wis Rahina, Kembang Mai, and Sepuran).

Fad (2014) identifies and classifies traditional games to grow the character of the early child into two, the traditional gestures or physical games that stimulate early childhood social skills (Sobyung, Ambah-ambah Lemah, Obar-abir, Jenthungan or Dhelikan, Bedhekan or Tutup Tutup, Dhakon, and Sundamanda or Engklek) as well as traditional games of motion and songs that stimulate early child social skills (Cublak Suweng, Jamuran, Gundhul-gundhul Pacul, Jaranan, Uler Keket, Kidang Talun, Kursi Jebol, Lagu Kacang Goreng,, Sluku-sluku Bathok, Siji Loro Telu, Menthogmenthog, and Buta-buta Galak). Here is an analysis of some of the traditional games for children (Table 1).

Table 1

Traditional Games for Children

\begin{tabular}{|c|c|c|c|}
\hline No & Name & How to Play & Expected Character Indicators Appear \\
\hline 1 & Kursi Jebol & $\begin{array}{l}\text { Children sing and move their limbs to adjust to } \\
\text { the songs and movements of other friends. there } \\
\text { are children who become montir and supir }\end{array}$ & $\begin{array}{l}\text { Movements made as a montir or supir can stimulate the } \\
\text { child to control himself when he becomes a leader (not } \\
\text { acting arbitrarily) and become a montir (obedient to } \\
\text { leader) }\end{array}$ \\
\hline 2 & Sobyung & $\begin{array}{l}\text { All the children sit in a circle while squatting and } \\
\text { playing fingers with certain patterns and rules }\end{array}$ & $\begin{array}{l}\text { All participants sit together and do not distinguish between } \\
\text { social, economic, religious or gender status. Early children } \\
\text { can learn to get to know the environment, playmates, and } \\
\text { neighbors around them when playing }\end{array}$ \\
\hline 3 & $\begin{array}{l}\text { Dhelikan, Bedhekan } \\
\text { or Tutup Mata }\end{array}$ & $\begin{array}{l}\text { Children who lose while doing hom pim pah will } \\
\text { become guardians who turn a blind eye and are in } \\
\text { charge of finding other children who are hiding }\end{array}$ & $\begin{array}{l}\text { Children learn to work with other members as well as } \\
\text { harmony between the role in charge of guarding and } \\
\text { hiding. Each child helps each other not to be easily found } \\
\text { by the guard. The patience of the child will also be trained } \\
\text { if it must be a guard again because it can not find other } \\
\text { members }\end{array}$ \\
\hline
\end{tabular}

\section{CONCLUSION}

The addiction of digital games to children in Indonesia has caused many adverse impacts. Children experience a decrease in learning achievement, difficulties in emotional development, concentration, and thinking power so that the development of children can be disrupted. The impact of addiction to digital games in children is a problem that must be addressed so that no degeneration of the nation's character. Related parties should work together to overcome the problem of digital game addiction in children. Parents should be aware that addictions in the use of technology such as TV, internet, and digital games can harm children. Parents should increase supervision of children.

Parents need to be aware of the duty as protector, educator, and person in charge so that parents can spend time and become friends for the child. Attention and affection, religious knowledge, and role models for children in behavior can protect children from addiction and bad behavior. Teachers and early childhood education institutions should also protect and educate children. Teachers can work with parents to replace and avoid technological tools with traditional games. The government as the party responsible for organizing and fostering the community must create a traditional game facility so that the character formation of the nation can run optimally. The traditional game should be a game of Indonesian children by awakening all parties in order to introduce and play traditional games with children.

\section{REFERENCES}

[1] Fad, A. 2014. Permainan Anak Tradisional Indonesia. Jakarta: Cerdas Interaktif (Penebar Swadaya Group).
[2] Kementrian Pendidikan dan Kebudayaan. 2014. Buku Panduan Pendidik Kurikulum 2013 PAUD: Anak Usia 5-6 Tahun. Jakarta: Kementrian Pendidikan dan Kebudayaan

[3] Munir, A. 2010. Pendidikan Karakter: Membangun Karakter Anak Sejak dari Rumah. Yogyakarta: Pedagogia.

[4] Mutiah, D. 2010. Psikologi Bermain Anak Usia Dini. Jakarta: Kencana.

[5] Nugraha, A., \& Rachmawati, Y. 2014. Modul Pengembangan Sosial Emosional. Banten: The Open University.

[6] Shin, Y. J. 2013. Mendidik Anak di Era Digital. Jakarta: Noura Books. 